\title{
Inquiry Learning Behaviors captured through Screencasts in Problem-Based Learning
}

This study examined the types of learning behaviors students demonstrated while performing inquiry tasks. It also explored the relations between the learning behaviors and students' domain knowledge. We observed fourteen students in five groups during a ninthgrade biology course. Three types of learning behaviors (inquiry, collaborative, and minimally productive behaviors) were identified and time on each type was measured. The results demonstrate that students demonstrated different patterns according to the types of learning behaviors. Correlation analysis revealed that learning outcomes had a strong positive correlation with the inquiry behaviors but a strong negative correlation with the minimally productive behaviors. The results suggest that attention should be paid to facilitate the more meaningful inquiry behaviors while reducing minimally productive behaviors.

Keywords: Problem-Based Learning; Inquiry Learning; Learning Behaviors; Collaborative Learning; Inquiry Behaviors

\section{Introduction}

Problem-based learning (PBL) can be defined as learning that results through facilitated, collaborative investigation within a complex and meaningful problem (Hmelo-Silver, 2004; Hmelo-Silver, Duncan, \& Chinn, 2007). One critical feature of PBL is scaffolded inquiry to enhance learning outcomes, such as the gains in content knowledge or the development of problem-solving skills (Kim \& Hannafin, 2011a; Raes, Schellens, De Wever, \& Vanderhoven, 2012; Saye \& Brush, 2002). Considering that PBL involves collaborative learning strategies, examining student interactions during group activities is important in order to understand students' inquiry learning processes (Simons \& Klein, 2007).

Although PBL involves group activities as a central means by which learning outcomes are attained (Hmelo-Silver, 2004), the learning behaviors of individual students need to be 
considered within the collaborative context (Belland, Burdo, \& Gu, 2015). Researchers exploring computer supported collaborative learning (CSCL) offer insight into how individual and group behaviors may be best understood by using tools that enable the ability to track team and individual activities. For example, Dwyer (2016) utilized screencast software to capture and analyze student's Internet inquiry behaviors, which enabled her to examine students' inquiry processes and determine what kinds of scaffolding they needed to support specific inquiry activities. Hazzard (2014) used screencast software to capture students' collaborative inquiry processes and trace "the evolution of students' thinking" (p. 58).

It is important to observe students' individual behaviors while engaged in PBL activities, since those behaviors may affect group interactions (Belland et al., 2015). This is especially true when students conduct problem-based tasks in a technology-enhanced learning environment, as their individual learning behaviors in the system significantly affect their inquiry processes (Edelson, Gordin, \& Pea, 1999). Given that individual students interact with each other and their learning behaviors may affect the group dynamics, observing individual students' problemsolving processes within a group context is critical to better understanding of how students carry out the inquiry task and how it affects learning outcomes.

\section{Types of Learning Behaviors in PBL}

PBL requires leaners to engage in complex and self-directed practices throughout the problemsolving process, including managing information, developing and testing hypotheses, evaluating evidence, and constructing arguments (Belland, Glazewski, \& Richardson, 2011). Previous studies have noted that PBL provides learners with opportunities for not only developing a deeper understanding of domain-specific knowledge but also for enhancing students' positive participation and rich collaboration (Hmelo-Silver et al., 2007; Shih, Chuang, \& Hwang, 2010). 
However, depending on their prior knowledge, experience, and abilities, learners need different amounts of support from their peers, teacher, or technology in order to successfully engage in inquiry (Edelson et al., 1999; Kim \& Hannafin, 2011b). The current study identified different types of learner behaviors involved in PBL activities, including inquiry behavior, collaborative behavior, and minimally productive behavior.

\section{Inquiry Behavior in PBL}

The National Research Council (2000) stated that scientific inquiry refers to the various ways in which scientists study the natural world and propose explanations based on the evidence derived from their work, which is consistent with the types of activities enacted in PBL (Ge, Law, \& Huang, 2016; Hmelo-Silver, 2004). As a result, inquiry in PBL can provide valuable experiences and opportunities for students to improve their understanding of both science content and scientific practices (Belland, Walker, Kim, \& Lefler, 2017; Kolodner et al., 2003).

Numerous researchers have addressed different forms of student behaviors during inquiry. For instance, Kim and Hannafin (2011a) identified five types of students' inquiry behaviors in science education: (a) problem identification and engagement, (b) evidence exploration, (c) explanation reconstruction, (d) communication and justification of an explanation, and (e) revision and reflection on an explanation. Quintana et al. (2004) outlined three main components of the inquiry process. "Sense making" relates to the foundational steps of testing hypotheses and interpreting data. "Process management" refers to control over the inquiry process through strategic decisions. Finally, "articulation and reflection" describes how learning outcomes are constructed, evaluated, and articulated. The progression of these inquiry activities is not necessarily linear; there are multiple ways to approach and conduct inquiry 
(Abrams, Southerland, \& Evans, 2008). As such, students' inquiry behavior may vary according to differences in curriculum design or learning environments.

\section{Collaborative Behavior}

Collaboration and communication skills are central to PBL classroom settings since students are expected to work together as a group to achieve a shared goal and to communicate their ideas with their peers (Rummel \& Spada, 2005). Collaborative learning environments facilitate opportunities for students to improve their capacity for constructive engagement in collaborative problem solving (Dillenbourg, 1999; Strijbos, Martens, Jochems, \& Broers, 2007).

Several researchers have explored learners' collaborative learning behaviors through their interactions with group members during group discussion (Fung, To, \& Leung, 2016) and group regulation (Barron, 2000; Kwon, Hong, \& Laffey, 2013). While solving a problem, student involvement in group discussion entails the exchange of knowledge, the co-construction of meaning, and the development of domain-specific knowledge and problem-solving skills (Johnson, Johnson, Stanne, \& Garibaldi, 1990; Zheng \& Huang, 2016). Specifically, group discussion enables learners not only to debate and develop their ideas and alternative hypotheses but also to evaluate and revise their findings, a process which may have a positive impact on group performance (Fung et al., 2016). In addition, literature focusing on collaborative or cooperative learning has highlighted the importance of group regulation with regards to successful group collaboration (Barron, 2000; Olson, Malone, \& Smith, 2001). The goal of group regulation includes establishing mutual knowledge and common understanding of tasks or goals, and reaching a shared task alignment in order to distribute responsibilities for completing the task among group members (Järvelä et al., 2016; Rummel \& Spada, 2005). 
While a number of collaborative behaviors that may affect learner achievement have been identified (e.g., Mercier, Higgins, \& da Costa, 2014; Sinha, Rogat, Adams-Wiggins, \& HmeloSilver, 2015), little research has explored how collaborative behaviors may be associated with other types of behaviors within a computer-supported inquiry learning environment.

Considering that students' collaborative behaviors may manifest themselves in various ways, further research needs to be conducted regarding how collaborative behaviors may affect other types of learner behaviors in PBL.

\section{Minimally Productive Behavior}

Although a number of studies have attested to the benefits of PBL, some researchers have reported challenges in student engagement during PBL activities in technology-enhanced classroom environments (Kim \& Hannafin, 2011a; Zhang \& Quintana, 2012). Researchers have found that learners are sometimes superficially involved during PBL activities, and may instead engage in unproductive behaviors such as disorientation or demotivation (Dias, Gomes, \& Correia, 1999; Ruthven, Hennessy, \& Deaney, 2005), poor search skills (Kuiper, Volman, \& Terwel, 2005), and repetitive tasks that do not relate to inquiry (Wallace, Kupperman, Krajcik, \& Soloway, 2000).

For example, Kim and Hannafin (2011a) found that some students who were classified as "unfocused trial-and-error students" often sought out information without a clear focus or goal. These types of learners showed less interest in exploring the problem, spending more than $50 \%$ of their time on off-task activities including online games or exploring websites unrelated to the topic. Similarly, Zhang and Quintana (2012) observed 6th graders' online inquiry activities at a public high school and found those students engaged in off-task behaviors such as personal talk, looking at irrelevant pictures, or off-topic chatting with peers. These types of behaviors occurred 
when learners failed to find relevant information, and when they carried out tedious tasks such as documenting bibliography information. Thus, further investigation of learners' minimally productive behaviors may be useful in order to facilitate the design effective learning materials and better support students' problem solving activities.

\section{Prior Knowledge}

Given that PBL activities involve a series of inquiry process and collaborative group work, it is important to investigate how students' inquiry-behaviors are associated with their learning outcomes. Individual learners come to classrooms with different prior knowledge, beliefs, and motivation (Bransford, Brown., \& Cocking., 1999; Prince \& Felder, 2006). These factors may interact with the learning tasks and group interaction patterns in PBL settings which may impact how students learn the target concepts and skills. In addition, students' prior knowledge in a specific domain may influence their knowledge recall, comprehension, and reasoning during

problem-solving processes (Kalyuga, Chandler, Tuovinen, \& Sweller, 2001; Müller-Kalthoff \& Möller, 2003; Thompson \& Zamboanga, 2004). For example, learners with higher prior knowledge related to a problem can more efficiently analyze and synthesize information presented in a digital format, which may result in deeper learning and better solutions to the problem (Lawless, Schrader, \& Mayall, 2007; Song, Kalet, \& Plass, 2016; Sullivan \& Puntambekar, 2015). Examining the relationship between learners' prior knowledge and different types of PBL behaviors may provide a better understanding of learners' inquiry learning and group interactions along with their understanding of content knowledge, especially in mobile learning environments. 


\section{Purpose of Study}

The purpose of this study was to identify the types of learning behaviors exhibited by students during PBL activities, to explore the similarities and differences in those behaviors based on student domain knowledge, and to examine the relationship between those behaviors and gains in domain knowledge. Specifically, the current study focused on the following research questions:

(1) What types of learning behaviors do students demonstrate during problem-based learning?

(2) What is the relationship between prior domain knowledge and the types of learning behaviors demonstrated by students?

(3) What is the relationship between the types of learning behaviors demonstrated by students and their conceptual understanding of the PBL topic?

\section{Method}

\section{Research Design and PBL Context}

This study employed an interpretive case study design which allowed us to examine a specific phenomenon occurring within the overall PBL unit. The main approach of this study was to describe students' learning behaviors (as interpreted by the researchers) and to analyze the relationship between the learning behaviors and student knowledge (Merriam, 1988).

The study took place during the 2015 spring semester in a 9th-grade biology course comprised of six classes taught by the same teacher in a rural community in the Midwestern United States. The teacher designed, developed and implemented a problem-based unit that engaged students in the topic of appropriate use of genetic information. This course was designed to promote students' inquiry and problem-solving skills by addressing scientific issues 
while interacting with web-based learning materials. All students in this course had their own Chromebook and accessed the web-based inquiry unit in order to investigate resources, find evidence, and create a group presentation while conducting the group task.

\section{Participants}

Among the 163 students who signed a consent form, twelve groups from six classes were initially selected and observed. However, seven groups in which at least one member was absent during implementation were excluded from the study. As a result, fourteen students ( 5 males, 9 females) from five groups were included in this study (see Table 1). The teacher grouped students based on their preferences, and each group had been collaborating on various class activities throughout the school year.

$>$ Insert Table $1<<$

\section{Unit Development}

In this study, the teacher developed the unit within a web-based learning environment known as the Socio-Scientific Inquiry Network (SSINet, http://education.indiana.edu/ssinet). SSINet supports teachers in their design and implementation of inquiry-based curricula with a variety of tools and resources. SSINet scaffolding tools enable teachers to create and manage their activities and resources to support science inquiry learning. The tools also assist teachers in the design of scaffolds that can be embedded into activities to support learners' performance, constrain the task, and help the teacher provide additional support to students during unit implementation (Brush et al., 2013; Brush et al., 2016). For example, in this unit students accessed specific resources via an online 'Activity Viewer.' When they clicked the links embedded on the left side of the panel, the hyperlinked resources such as articles or video clips 
appeared on the main content panel (see Figure 1).

$>$ Insert Figure $1<<$

The specific unit that the teacher developed focused on issues related to the appropriate use of genetic information. The driving question for the unit was "What laws should we have to govern the use of genetic information in health insurance, employment, life insurance, and long term care insurance?" Unit activities were sequenced over a period of six days, and included several specific activities designed to assist students with both acquiring the content knowledge necessary to address the driving question, and construct presentations to present their solutions to the question (see Table 2).

$$
>>\text { Insert Table } 2<<
$$

Although all of the unit activities were designed to facilitate students' engagement with the driving question, a majority of student collaboration (e.g., identifying issues, developing claims and evidence, evaluating and monitoring group work) occurred during the culminating activity. Thus, the researchers focused their data collection and analysis on collaborative activities that took place during this phase of the unit.

\section{Procedure}

Before implementing the unit, the teacher explained the purpose of study and distributed the consent forms to students and their parents. He then administered a pretest focusing on genetics content knowledge to the students.

The unit was implemented over a period of six days within a three-week timeframe. Each class was 90 minutes long. On the first day of unit, the teacher introduced the topic and students watched videos related to the driving question. On the days two and three, students 
were engaged in 'Jigsaw' and 'Whiteboard' activities designed to provide students with necessary content focusing on the topic of genetics in order to prepare them to successfully address the driving question for the unit. On days four and five, the teacher assigned students to groups in which they were required to develop their perspectives (supported with evidence) regarding the driving question. On the final day of the unit, each group delivered a 10-minute presentation addressing the driving question, and answered questions from other groups. After completing the group presentations, a posttest covering the same content as the pretest was administrated to the students.

\section{Data Sources and Analysis}

Data regarding student behaviors while engaged in PBL unit activities were collected for fourteen students using an application entitled "MediaCore." This application was installed on each student's individual Chromebook, and allowed for the capture of "screencasts" which included screen movements and student audio and video while engaged in unit activities via the Chromebook. The researchers analyzed the screencasts as a primary data source for individual student behaviors. In addition, the researchers analyzed video recordings of group acitvities in order to examine group interactions that occurred during PBL activities.

In order to analyze student learning behaviors, we employed qualitative content analysis procedures (Newby, 2014). The unit of analysis was individual behaviors analyzed using screencast data. The results of qualitative content analysis were quantified in terms of time engaged in a specific behavior for further analysis (Chi, 1997). A correlation analysis was then carried out to attempt to determine whether there was a correlation between time engaged in a specific behavior and content knowledge both prior to participating in PBL activities and after completing PBL activities. 


\section{Measurement}

\section{Content knowledge}

A 23-item online test was administrated before (pre-test) and after (post-test) the inquiry activities to assess students' content knowledge related to genetics. The teacher developed the test which consisted of 21 multiple-choice questions and two essay questions. Students could earn up to 27 points; each multiple-choice item was worth one point and each essay question was worth three points.

\section{Learning behaviors}

Students' learning behaviors were identified through the analysis of screencasts. The researchers developed a coding scheme based on the literature review and the recursive refinement process to analyze the types of learning behaviors in the inquiry-based learning. It includes three categories: inquiry, collaborative, and minimally productive behaviors, and additional subgroups of these learning behavior categories that were observed (see Table 3).

A total of six coders carried out the coding process based on this analysis framework. Two coders were paired to analyze one participant's video recording independently. In order to avoid systematic bias between coders, different pairs of coders analyzed different video recordings by changing the partnership after completing one set of data (Hallgren, 2012). The coders segmented the video recording into units of meaning in accordance with the coding scheme and reached consensus on the segmentations before coding. About $60 \%$ of data were analyzed with this method and the initial inter-rater reliabilities reached the "Almost Perfect" agreement levels (Category: Kappa $=.87$; Learning behaviors: Kappa $=.84$ ) (Landis $\&$ Koch, 1977, p. 165). The initial disagreements were resolved through negotiation between the coders 
and the lead researcher. Once the reliability of the coding framework was established, the researchers completed the content analysis of the remaining data individually.

$$
>\text { Insert Table } 3<<
$$

\section{Results}

\section{Types of learning behaviors}

Researchers examined students' learning behaviors captured through the screencast software. Based on the descriptive results of content analysis, learning behaviors were identified for each group. Table 4 summarizes the learning behaviors observed during the inquiry activities.

$$
>\text { Insert Table } 4<<
$$

\section{Inquiry behaviors}

Overall, students demonstrated inquiry behaviors for approximately $36 \%$ of their total learning time. For the inquiry behaviors, students spent most of time engaging in learning activities, reviewing learning materials given by the teacher, and exploring other websites to get additional information related to the task ( $86 \%$ of the inquiry behaviors). It is noteworthy that students explored external websites (19\%) in addition to reviewing learning materials provided by the teacher (38\%). This may suggest that students were actively searching for additional information beyond the materials provided by the teacher to assist with addressing the driving question.

Only $10 \%$ of the inquiry behaviors exhibited by students involved them interacting with the teacher (e.g., asking the teacher for clarification or additional information). This suggests that 
the students tended to conduct the task fairly independently. Students spent no more than $5 \%$ of the time they spent engaged in inquiry summarizing and highlighting the relevant information.

For example, one student engaged in activities where she appeared to be reading and exploring learning resources to facilitate her own inquiry processes, the student appeared to ask questions to herself when speaking at a low volume while reviewing the resources. Other students appeared to be thinking and experiencing "ah ha" moments. For example, on two occasions during a thirty-minute observation, a student reviewing her group's online presentation said aloud, "I think I've got it" and then proceeded to explain a specific point without entering additional content.

\section{Collaborative behaviors}

Students' collaborative behaviors were also observed with limited amounts ( $18 \%$ of total time). Discussion was the most frequent behavior that occurred in groups $(86 \%$ of the collaborative behaviors) while coordination of group work occurred less frequently (14\%). Other examples of collaborative behavior included connecting ideas generated from student discussions, commenting or clarifying another student's input, and recapping discussions. For example, among a particular group of students, three had been discussing whether to emphasize the distinction between stress and anxiety or focus on the long-term effects associated with stress and anxiety. One student stated that the discussion seemed to be about being afraid to share genetic information, which prompted another student to begin a search with the keywords "fear of genetic information." Thus, one student contributed information relevant to the group discussion, which influenced the direction and focus of the group effort. 


\section{Minimally productive behaviors}

Analysis of the data indicated that students spent over $40 \%$ of the time engaged in the task on activities that were either unrelated or minimally related to the task itself. Approximately 11\% of the student time was spent on what researchers categorized as "superficial learning activities"; i.e., activities that were necessary to complete course assignments and tasks but did not require problem solving in order to better address the driving question. Examples of these behaviors included exploring web sites without reviewing content for relevance, locating images, highlighting text, and formatting the final presentation to enhance the visual appearance of the presentation (see Table 4). For example, analysis of screencast data revealed that students spent a great deal of their time using the layout and font tools to change the appearance, color, and display features of their presentations. Other examples included spending time searching for images and then resizing or formatting those images to include them in their presentations.

Analysis of data also revealed that students spent approximately $30 \%$ of the time engaged in activities that were unrelated to the task. Examples of these behaviors included participating in personal chat sessions with friends/peers or browsing non-task related websites. For example, one student group had begun negotiating roles and responsibilities for their presentation project when one of the group members asked about how to earn a job. The discussion then turned to how much money to ask for and then what each would like to buy with their money. One student typed "Rolex" in their web browser and clicked on images. The other students gathered around the screen to look at images of watches. This activity drew the group's attention away from discussing the course and generating subject-matter knowledge. 


\section{Group differences in the types of learning behaviors}

The researchers used results of student pre-tests to classify student groups as "low prior knowledge" (LK) or "high prior knowledge" (HK). Two groups were classified as LK (n = 4, M $=6.25, \mathrm{SD}=1.89)$, while three were classified as $\mathrm{HK}(\mathrm{n}=10, \mathrm{M}=10.8, \mathrm{SD}=2.39)$. The pretest results for the overall population of students participating in the PBL unit activities $(n=151)$ revealed a mean pretest score of $8.8(\mathrm{SD}=3.12)$.

Results suggested that groups demonstrated different patterns of behaviors based on their level of prior knowledge. For example, in the two groups classified as "LK," team A demonstrated higher levels of inquiry behaviors $(53 \%)$ and lower levels of minimally productive behaviors (39\%) compared to team B (10\% and 90\% respectively). The three groups classified as " $\mathrm{HK}$ " demonstrated varying levels of inquiry behaviors, ranging from $15 \%$ to $61 \%$. Similarly, the HK groups had a wide range of minimally productive behaviors (ranging from 17\% to 63\%). Consistent with the results of the LK groups, HK groups that demonstrated high levels of inquiry behaviors tended to demonstrate low levels of minimally productive behaviors, and vice versa.

The researchers also examined the differences in collaborative behaviors between the LK groups and the HK groups. Results suggest that the HK groups demonstrated more frequent

collaborative behaviors than the LK groups (see Table 4). Results of a Mann-Whitney U test indicated that the HK groups demonstrated more collaborative behaviors ( $\mathrm{Mdn}=9.3)$ than the LK groups $(\mathrm{Mdn}=3.0), \mathrm{U}=38.00, \mathrm{p}=.008$.

\section{Relationships between learning behaviors and domain knowledge}

In order to examine the relations between the learning behaviors and students' domain knowledge, the researchers conducted Pearson correlation analyses of both the proportion of 
time spent on various behaviors as a percentage of total learning time, as well as the actual time spent on those behaviors, which would enhance the validity of interpretation and reduce any potential bias caused by the different total time across individuals. Table 5 describes the intercorrelations between the types of learning behaviors and domain knowledge assessed individually before (via the pre-test) and after (via the post-test) the inquiry learning activities.

The analyses of two sets of data revealed similar patterns. First, students' prior domain knowledge and their collaborative behaviors were positively correlated in proportion, $r(12)=$ $.77, p<.001$ and in actual time, $r(12)=.59, p<.05$. Second, the post-test scores revealed strong correlations with the inquiry behaviors in proportion, $r(12)=.77, p<.001$ and in actual time, $r(12)=.72, p<.001$. The post-test scores and the minimally productive behaviors were also strongly negatively correlated in proportion, $r(12)=-.80, p<.001$ and in actual time, $r(12)=-$ $.74, p<.001$. Third, there was strong negative correlation between the inquiry and the minimally productive behaviors in proportion, $r(12)=-.91, p<.001$ and in actual time, $r(12)=$ $.57, p<.01$.

Researchers found a significant positive relation between the inquiry and collaborative behaviors from the actual time data set, $r(12)=.62, p<.05$. There was also significant negative correlation between the minimally productive and collaborative behaviors in the proportion data set, $r(12)=-.60, p<.05$.

In summary, analysis of the relationship between student behaviors and domain knowledge revealed that: (1) students who had higher prior domain knowledge demonstrated more collaborative behaviors; (2) students who demonstrated more inquiry behaviors achieved higher post-test scores; (3) students who demonstrated more minimally productive behaviors 
achieved lower post-test scores, and; (4) students who demonstrated more collaborative behaviors also exhibited more inquiry behaviors but less minimally productive behaviors.

>> Insert Table $5<<$

\section{Discussion}

The purpose of this study was to identify the types of learning behaviors students engaged in during PBL activities, and to examine the relationships between those behaviors and learning outcomes. Results suggest that students had spent half of learning time in inquiry processes and collaboration (research question 1), students with higher prior knowledge demonstrated a higher level of collaborative behaviors but not a higher level inquiry behaviors (research question 2), and the level of inquiry behavior had a strong positive correlation to learning outcomes (as measured by the post-test), while the amount of minimally productive behaviors showed a strong negative correlation with learning outcomes (research question 3).

\section{Inquiry behaviors}

The inquiry processes in this study required students to engage with the content not by listening to the teacher's explanation but by carrying out inquiry activities by themselves. We hypothesize that teacher's learning materials may have played a supporting role in initiating student questions and guiding the inquiry process. Interestingly, students extended their exploration of content to websites that were not provided by the teacher. The flexible learning environment may have promoted independent inquiry processes as intended by the teacher's inquiry-based learning design. Similar to the results of other studies examining the effect of inquiry learning, these inquiry behaviors were closely associated with positive learning outcomes 
(Justice, Rice, Warry, \& Laurie, 2007; Minner, Levy, \& Century, 2010).

Results of this study did not reveal a relationship between students' prior knowledge and level of inquiry behaviors. This may suggest that individual inquiry behaviors are independent from their level of domain knowledge. In other words, students with low levels of prior knowledge may still be successful in inquiry-based activities. Recent research demonstrating that students with low prior knowledge successfully engaged in PBL activities supports this hypothesis (Glazewski, Brush, Shin, \& Shin, 2016, June).

While interpreting the results, we need to consider the following limitations. The researchers measured students' inquiry behaviors mainly through their information seeking behaviors captured by the individual learning device. In this study, transformative inquiry processes referring to generation of new knowledge such as analysis and interpretation of data, hypothesis generation, and evaluation were observed by the following coding scheme: "engage in learning activities", "summarize findings", and "discussion" behaviors (Njoo \& De Jong, 1993). However, researchers did not analyze the types of transformative inquiry processes but focused on inquiry behaviors observed through individual screens because the inquiry tasks did not request the students to validate hypotheses or develop a model. Thus it seemed that students did not need to heavily rely on their prior knowledge for finding and analyzing data (e.g., Gijlers \& de Jong, 2005). However, it was suggested that their inquiry behaviors affected their knowledge acquisition afterward.

\section{Collaborative behaviors}

Regarding group discussions, students who had higher prior knowledge engaged in discussion more actively $(19.8 \%)$ than those who had lower prior knowledge $(3.8 \%)$. The phenomenon can be explained by their understanding of the inquiry topics. Gijlers and de Jong (2005) found that 
when students had higher domain knowledge, they more frequently discussed the interpretation of inquiry data. They also suggested that students tended to discuss their inquiry process when more knowledgeable students collaborate with less knowledgeable ones. The difference of prior knowledge may have triggered knowledge exchanges between them (Webb, 1980). However, homogeneous groups being consisted of same prior knowledge levels without high knowledgeable students had a limited discussion, which did not positively affect their learning. Results of the current study suggest that students who were active in discussion demonstrated more inquiry behaviors as well as less minimally productive behaviors in general. The collaborative behaviors may have facilitated the inquiry behaviors while controlling the minimally productive behaviors. Although direct relation between the collaborative behaviors and the post-test scores was not confirmed in this study, future research may want to examine this potential relationship.

\section{Minimally productive behaviors}

Results of this study suggest two types of learning behaviors that were negatively correlated with learning outcomes. It was not surprising that the off-task behaviors contributed to the results. However, the results also revealed some learning behaviors were not beneficial when the behavior were not related to inquiry but instead focused on non-inquiry tasks (e.g., focusing on the visual design aspects of the presentation).

Active engagement in the inquiry process is considered critical for successful problembased learning. The term "active" does not mean that students are simply "busy" from a behavioral perspective but rather that they are involved in meaningful learning that addresses the driving question (Chi \& Wylie, 2014). One can differentiate "superficial" from "meaningful" learning based on how learners utilize knowledge during problem solving (Sins, van Joolingen, 
Savelsbergh, \& van Hout-Wolters, 2008). If a certain behavior would help learners construct knowledge, it was considered an inquiry behavior. However, if the behavior was performed only to complete the task without regarding for learning, it was considered "superficial" learning. Similarly to results of previous studies, this study suggests that behaviors that were classified as "superficial" did not facilitate positive learning outcomes (Sins, Savelsbergh, van Joolingen, \& van Hout-Wolters, 2011; Sins et al., 2008).

It is worth noting that the students who demonstrated a higher level of off-task behaviors also exhibited behaviors that would be classified as "superficial," such as unfocused web surfing. Disengaged students were "hopping" from website to website without carefully reading content, and focusing on finding stories related to the task without considering arguments to address the driving question. Thus, this research suggests that teachers should consider methods to reduce superficial behaviors in order to fully engage all students in meaningful inquiry processes.

\section{Limitation}

The main limitation to this study arises from the small number of participants that causes the lack of generalizability. The study was conducted in one single research site of utilizing a particular web-based learning environment. Although this study had closely examined the inquiry learning behaviors observed in a typical technology-enhanced classroom environment, the results heavily relied on the context. For better understanding, it would be helpful to examine the interactions between the types of collaborative behaviors and learner characteristics such as genders and preference toward collaboration in addition to their prior knowledge. The results could have been also affected by the uneven group size and different gender composition that were not controlled in the study. However, further analyses of these factors that might give us better insights in guiding the students during the inquiry process were not feasible due to the limited numbers of 
participants.

\section{Conclusion}

In this study, we identified the types of learning behaviors that students had demonstrated during inquiry learning. The results suggest a strong positive relationship between inquiry behaviors and learning outcomes. On the other hand, minimally productive behaviors consisting of offtask and superficial learning were negatively correlated with the learning outcomes. These findings may provide opportunities to explore research areas involving methods for facilitating meaningful inquiry behaviors while reducing superficial learning activities. This study also examined the types of collaborative behaviors that were positively related to inquiry behaviors but negatively related to minimally productive behaviors. Further research may want to focus on the relationships among the behavior types and explore their effects on learning outcome in various learning contexts.

\section{Reference}

Abrams, E., Southerland, S. A., \& Evans, C. (2008). Introduction. Inquiry in the classroom: Identifying Necessary Components of a Useful Definition. In E. A. Abrams, S. A. Southerland, \& P. Silva (Eds.), Integrating inquiry in the classroom: Realities and opportunities (pp. 6-42). Charlotte, NC: Information Age Publishing.

Barron, B. (2000). Achieving coordination in collaborative problem-solving groups. The Journal of the Learning Sciences, 9(4), 403-436. doi:10.1207/S15327809JLS0904_2

Belland, B. R., Burdo, R., \& Gu, J. (2015). A Blended Professional Development Program to Help a Teacher Learn to Provide One-to-One Scaffolding. Journal of Science Teacher Education, 26(3), 263-289. doi:10.1007/s10972-015-9419-2

Belland, B. R., Glazewski, K. D., \& Richardson, J. C. (2011). Problem-based learning and argumentation: testing a scaffolding framework to support middle school students' 
creation of evidence-based arguments. Instructional Science, 39(5), 667-694.

doi:10.1007/s11251-010-9148-z

Belland, B. R., Walker, A. E., Kim, N. J., \& Lefler, M. (2017). Synthesizing Results From Empirical Research on Computer-Based Scaffolding in STEM Education. Review of Educational Research, 87(2), 309-344. doi:10.3102/0034654316670999

Bransford, J. D., Brown., A. L., \& Cocking., R. R. (1999). How people learn: Brain, mind, experience, and school. Washington, DC: National Academy Press.

Brush, T., Glazewski, K., Ottenbreit-Leftwich, A., Saye, J., Zhang, Z., \& Shin, S. (2013). The PBL-TECH Project: Web-based tools and resources to support problem-based learning in pre-service teacher education. In D. G. L. Liu \& C. Maddux (Eds.), Research Highlights in Technology and Teacher Education 2013 (pp. 91-100). Chesapeake, VA: Society for Information Technology \& Teacher Education.

Brush, T., Shin, S., Shin, S., Jung, J., Gensic, J., \& Glazewski, K. (2016). Design and Implementation of a Technology-Supported Socioscientfic Inquiry Unit in High School Biology. International Journal of Designs for Learning, 7(2), 1-10.

Chi, M. T. H. (1997). Quantifying Qualitative Analyses of Verbal Data: A Practical Guide. Journal of the Learning Sciences, 6(3), 271-315. doi:10.1207/s15327809jls0603_1

Chi, M. T. H., \& Wylie, R. (2014). The ICAP Framework: Linking Cognitive Engagement to Active Learning Outcomes. Educational Psychologist, 49(4), 219-243. doi:10.1080/00461520.2014.965823

Dias, P., Gomes, M. J., \& Correia, A. P. (1999). Disorientation in Hypermedia Environments: Mechanisms to Support Navigation. Journal of Educational Computing Research, 20(2), 93-117. doi:10.2190/G8C5-342V-DJX3-Q53F

Dillenbourg, P. (1999). What do you mean by 'collaborative learning'? In P. Dillenbourg (Ed.), Collaborative-learning: Cognitive and Computational Approaches. (pp. 1-19): Oxford: Elsevier.

Dwyer, B. (2016). Engaging All Students in Internet Research and Inquiry. The Reading Teacher, 69(4), 383-389. doi:10.1002/trtr.1435

Edelson, D. C., Gordin, D. N., \& Pea, R. D. (1999). Addressing the Challenges of Inquiry-Based Learning Through Technology and Curriculum Design. Journal of the Learning Sciences, 8(3-4), 391-450. doi:10.1080/10508406.1999.9672075 
Fung, D. C.-L., To, H., \& Leung, K. (2016). The influence of collaborative group work on students' development of critical thinking: The teacher's role in facilitating group discussions. Pedagogies: An International Journal, 11(2), 146-166. doi:10.1080/1554480X.2016.1159965

Ge, X., Law, V., \& Huang, K. (2016). Detangling the Interrelationships Between Self-Regulation and Ill-Structured Problem Solving in Problem-Based Learning. Interdisciplinary Journal of Problem-based Learning, 10(2). doi:10.7771/1541-5015.1622

Gijlers, H., \& de Jong, T. (2005). The relation between prior knowledge and students' collaborative discovery learning processes. Journal of Research in Science Teaching, 42(3), 264-282. doi:10.1002/tea.20056

Glazewski, K., Brush, T., Shin, S., \& Shin, S. (2016, June). Implementing socioscientific inquiry in high school biology: Teacher and student perspectives. Paper presented at the 2016 PBL Congress, Zurich, Switzerland.

Hallgren, K. A. (2012). Computing Inter-Rater Reliability for Observational Data: An Overview and Tutorial. Tutorials in Quantitative Methods for Psychology, 8(1), 23-34.

Hazzard, E. (2014). A New Take On Student Lab Reports. The Science Teacher, 81(3), 57-61.

Hmelo-Silver, C. E. (2004). Problem-Based Learning: What and How Do Students Learn? Educational Psychology Review, 16(3), 235-266. doi:10.1023/B:EDPR.0000034022.16470.f3

Hmelo-Silver, C. E., Duncan, R. G., \& Chinn, C. A. (2007). Scaffolding and Achievement in Problem-Based and Inquiry Learning: A Response to Kirschner, Sweller, and. Educational Psychologist, 42(2), 99-107. doi:10.1080/00461520701263368

Järvelä, S., Kirschner, P. A., Hadwin, A., Järvenoja, H., Malmberg, J., Miller, M., \& Laru, J. (2016). Socially shared regulation of learning in CSCL: understanding and prompting individual- and group-level shared regulatory activities. International Journal of Computer-Supported Collaborative Learning, 11(3), 263-280. doi:10.1007/s11412-0169238-2

Johnson, D. W., Johnson, R. T., Stanne, M. B., \& Garibaldi, A. (1990). Impact of group processing on achievement in cooperative groups. The Journal of Social Psychology, 130(4), 507-516. doi:10.1080/00224545.1990.9924613 
Justice, C., Rice, J., Warry, W., \& Laurie, I. (2007). Taking an "inquiry" course makes a difference: A comparative analysis of student learning. Journal on Excellence in College Teaching, 18(1), 57-77.

Kalyuga, S., Chandler, P., Tuovinen, J., \& Sweller, J. (2001). When problem solving is superior to studying worked examples. Journal of Educational Psychology, 93(3), 579-588. doi:10.1037/0022-0663.93.3.579

Kim, M. C., \& Hannafin, M. J. (2011a). Scaffolding 6th graders' problem solving in technologyenhanced science classrooms: A qualitative case study. Instructional Science, 39(3), 255282. doi:10.1007/s11251-010-9127-4

Kim, M. C., \& Hannafin, M. J. (2011b). Scaffolding problem solving in technology-enhanced learning environments (TELEs): Bridging research and theory with practice. Computers \& Education, 56(2), 403-417. doi:10.1016/j.compedu.2010.08.024

Kolodner, J. L., Camp, P. J., Crismond, D., Fasse, B., Gray, J., Holbrook, J., . . Ryan, M. (2003). Problem-Based Learning Meets Case-Based Reasoning in the Middle-School Science Classroom: Putting Learning by Design(tm) Into Practice. Journal of the Learning Sciences, 12(4), 495-547. doi:10.1207/S15327809JLS1204_2

Kuiper, E., Volman, M., \& Terwel, J. (2005). The web as an information resource in K-12 education: Strategies for supporting students in searching and processing information. Review of Educational Research, 75(3), 285-328. doi:10.3102/00346543075003285

Kwon, K., Hong, R., \& Laffey, J. M. (2013). The educational impact of metacognitive group coordination in computer-supported collaborative learning. Computers in Human Behavior, 29(4), 1271-1281. doi:10.1016/j.chb.2013.01.003

Landis, J. R., \& Koch, G. G. (1977). The Measurement of Observer Agreement for Categorical Data. Biometrics, 33(1), 159-174. doi:10.2307/2529310

Lawless, K. A., Schrader, P. G., \& Mayall, H. J. (2007). Acquisition of information online: Knowledge, navigation and learning outcomes. Journal of Literacy Research, 39(3), 289306. doi:10.1080/10862960701613086

Mercier, E. M., Higgins, S. E., \& da Costa, L. (2014). Different leaders: Emergent organizational and intellectual leadership in children's collaborative learning groups. International Journal of Computer-Supported Collaborative Learning, 9(4), 397-432. doi:10.1007/s11412-014-9201-z 
Merriam, S. B. (1988). Case study research in education: A qualitative approach. San Francisco, CA: Jossey-Bass.

Minner, D. D., Levy, A. J., \& Century, J. (2010). Inquiry-based science instruction-what is it and does it matter? Results from a research synthesis years 1984 to 2002. Journal of Research in Science Teaching, 47(4), 474-496. doi:10.1002/tea.20347

Müller-Kalthoff, T., \& Möller, J. (2003). The effects of graphical overviews, prior knowledge, and self-concept on hypertext disorientation and learning achievement. Journal of Educational Multimedia and Hypermedia, 12(2), 117-134.

Newby, P. (2014). Research Methods for Education (2 ed.). New York, NY: Routledge.

Njoo, M., \& De Jong, T. (1993). Exploratory learning with a computer simulation for control theory: Learning processes and instructional support. Journal of Research in Science Teaching, 30(8), 821-844. doi:10.1002/tea.3660300803

Olson, G. M., Malone, T., \& Smith, J. (2001). Coordination theory and collaboration technology. Mahwah, NJ: Lawrence Erlbaum Associates, Inc.

Prince, M. J., \& Felder, R. M. (2006). Inductive teaching and learning methods: Definitions, comparisons, and research bases. Journal of Engineering Education, 95(2), 123-138. doi:10.1002/j.2168-9830.2006.tb00884.x

Quintana, C., Reiser, B. J., Davis, E. A., Krajcik, J., Fretz, E., Duncan, R. G., . . Soloway, E. (2004). A scaffolding design framework for software to support science inquiry. Journal of the Learning Sciences, 13(3), 337-386. doi:10.1207/s15327809j1s1303 4

Raes, A., Schellens, T., De Wever, B., \& Vanderhoven, E. (2012). Scaffolding information problem solving in web-based collaborative inquiry learning. Computers \& Education, 59(1), 82-94. doi:10.1016/j.compedu.2011.11.010

Rummel, N., \& Spada, H. (2005). Learning to Collaborate: An Instructional Approach to Promoting Collaborative Problem Solving in Computer-Mediated Settings. Journal of the Learning Sciences, 14(2), 201-241.doi:10.1207/s15327809j1s1402_2

Ruthven, K., Hennessy, S., \& Deaney, R. (2005). Incorporating Internet resources into classroom practice: Pedagogical perspectives and strategies of secondary-school subject teachers. Computers \& Education, 44(1), 1-34. doi:10.1016/j.compedu.2003.11.001 
Saye, J. W., \& Brush, T. (2002). Scaffolding critical reasoning about history and social issues in multimedia-supported learning environments. Educational Technology Research and Development, 50(3), 77-96. doi:10.1007/bf02505026

Shih, J.-L., Chuang, C.-W., \& Hwang, G.-J. (2010). An inquiry-based mobile learning approach to enhancing social science learning effectiveness. Educational Technology \& Society, $13(4), 50-62$

Simons, K. D., \& Klein, J. D. (2007). The Impact of Scaffolding and Student Achievement Levels in a Problem-based Learning Environment. Instructional Science, 35(1), 41-72. doi:10.1007/s11251-006-9002-5

Sinha, S., Rogat, T. K., Adams-Wiggins, K. R., \& Hmelo-Silver, C. E. (2015). Collaborative group engagement in a computer-supported inquiry learning environment. International Journal of Computer-Supported Collaborative Learning, 10(3), 273-307. doi:10.1007/s11412-015-9218-y

Sins, P. H. M., Savelsbergh, E. R., van Joolingen, W. R., \& van Hout-Wolters, B. H. A. M. (2011). Effects of face-to-face versus chat communication on performance in a collaborative inquiry modeling task. Computers \& Education, 56(2), 379-387. doi:10.1016/j.compedu.2010.08.022

Sins, P. H. M., van Joolingen, W. R., Savelsbergh, E. R., \& van Hout-Wolters, B. (2008). Motivation and performance within a collaborative computer-based modeling task: Relations between students' achievement goal orientation, self-efficacy, cognitive processing, and achievement. Contemporary Educational Psychology, 33(1), 58-77. doi:10.1016/j.cedpsych.2006.12.004

Song, H. S., Kalet, A. L., \& Plass, J. L. (2016). Interplay of prior knowledge, self-regulation and motivation in complex multimedia learning environments. Journal of Computer Assisted Learning, 32(1), 31-50. doi:10.1111/jcal.12117

Strijbos, J.-W., Martens, R. L., Jochems, W. M. G., \& Broers, N. J. (2007). The effect of functional roles on perceived group efficiency during computer-supported collaborative learning: A matter of triangulation. Computers in Human Behavior, 23(1), 353-380. doi:10.1016/j.chb.2004.10.016 
Sullivan, S. A., \& Puntambekar, S. (2015). Learning with digital texts: Exploring the impact of prior domain knowledge and reading comprehension ability on navigation and learning outcomes. Computers in Human Behavior, 50, 299-313. doi:10.1016/j.chb.2015.04.016

Thompson, R. A., \& Zamboanga, B. L. (2004). Academic aptitude and prior knowledge as predictors of student achievement in introduction to psychology. Journal of Educational Psychology, 96(4), 778-784. doi:10.1037/0022-0663.96.4.778

Wallace, R. M., Kupperman, J., Krajcik, J., \& Soloway, E. (2000). Science on the Web: Students Online in a Sixth-Grade Classroom. The Journal of the Learning Sciences, 9(1), 75-104. doi:10.1207/s15327809j1s0901_5

Webb, N. M. (1980). A process-outcome analysis of learning in group and individual settings. Educational Psychologist, 15(2), 69-83. doi:10.1080/00461528009529217

Zhang, M., \& Quintana, C. (2012). Scaffolding strategies for supporting middle school students' online inquiry processes. Computers \& Education, 58(1), 181-196. doi:10.1016/j.compedu.2011.07.016

Zheng, L., \& Huang, R. (2016). The effects of sentiments and co-regulation on group performance in computer supported collaborative learning. The Internet and Higher Education, 28, 59-67. doi:10.1016/j.iheduc.2015.10.001 
Table 1. Characteristics of groups

\begin{tabular}{ccccc}
\hline Group & Gender & Number of students & Pretest & Posttest \\
\hline Group A & Females & 2 & 7 & 17.5 \\
Group B & Males & 2 & 5.5 & 15 \\
Group C & Males & 3 & 12 & 15 \\
Group D & Females & 4 & 9.75 & 16.5 \\
Group E & Females & 3 & 11 & 18 \\
\hline
\end{tabular}


Table 2. Inquiry-based learning activities

Learning activities Learning contents

Day 1: Entry event 1. The teacher provided an overview of the genetic information to introduce the driving question for the unit.

2. Students watched a video and discussed the following question: "what are the potential uses of genomic information?"

Day 2: Jigsaw

1. The jigsaw was designed to help student with developing fundamental genetic knowledge.

2. Students engaged in a jigsaw activity in which student groups were assigned one of seven trait types: polygenic, dominant, recessive, incompletely dominant, codominance, sex-linked, or multiply allelic, and asked to research the specific trait and share an overview of the trait to their classmates.

Day 3: White- board

1. Students reviewed information explaining that most traits of activity an organism were the result of proteins or a combination of proteins produced by transcription and translation.

2. After exploring the content with their peers, each group presented how their gene worked when it was activated and inactivated at the molecular level.

Day 4-6:

1. In the culminating activity, students were assigned to one of Culminating activity eight specific stakeholder positions (Theme Park Owner, Factory Owner, Person with Great genes, Insurance Company Executive, Doctor against use of genetic information, Factory Worker, Domestic Engineer, Math Teacher).

2. Each group was required to research their specific role and present the stakeholder's position regarding the use of genetic information to the rest of the class. 
Table 3. Content analysis frame

\begin{tabular}{|c|c|c|c|}
\hline Category & Learning behaviors & Code & Description \\
\hline \multirow{5}{*}{$\begin{array}{l}\text { Inquiry } \\
\text { Behavior } \\
\text { (IB) }\end{array}$} & $\begin{array}{l}\text { Engage in learning } \\
\text { activities }\end{array}$ & ENGAGE & $\begin{array}{l}\text { Identified problems and learning goals, and completed the task by } \\
\text { making a slide while answering the research questions }\end{array}$ \\
\hline & Explore learning sites & EXPLORE & Got useful information by exploring external websites \\
\hline & $\begin{array}{l}\text { Review the learning } \\
\text { materials }\end{array}$ & REVIEW & $\begin{array}{l}\text { Got useful information by reviewing the learning materials } \\
\text { provided by the teacher }\end{array}$ \\
\hline & Summarize findings & SUMMARY & Summarized and highlighted the information found \\
\hline & Ask questions & ASK & Asked questions to the teacher \\
\hline \multirow{2}{*}{$\begin{array}{l}\text { Collaborative } \\
\text { Behavior } \\
(\mathrm{CB})\end{array}$} & Group coordination & GROUP & Purposefully divided labor and took different roles for collaboration \\
\hline & Discussion & DISCUSS & Developed their arguments and negotiated to reach an agreement \\
\hline $\begin{array}{l}\text { Minimally } \\
\text { Productive }\end{array}$ & $\begin{array}{l}\text { Engage in surface } \\
\text { features of learning }\end{array}$ & SURFACE & $\begin{array}{l}\text { Prepared presentation by decorating slides (changing the fonts, } \\
\text { finding and inserting images etc.) }\end{array}$ \\
\hline \multirow[t]{3}{*}{$\begin{array}{l}\text { Behavior } \\
\text { (MPB) }\end{array}$} & Web surfing & SURF & $\begin{array}{l}\text { Jumped through several web pages without carefully reading } \\
\text { contents (usually spent less than } 5 \text { seconds on a page) }\end{array}$ \\
\hline & Off task & OFF & $\begin{array}{l}\text { Checked personal email, explored off-topic sites, or chatted } \\
\text { personal issues }\end{array}$ \\
\hline & Other & OTHER & $\begin{array}{l}\text { Any behavior that did not fall into the above sub-categories } \\
\text { (technical issues, eating etc.) }\end{array}$ \\
\hline No analysis & & & $\begin{array}{l}\text { Moments that were not related to education (changing seats, } \\
\text { disappear from the screen etc.) were excluded. }\end{array}$ \\
\hline
\end{tabular}


Table 4. Group's descriptive results of learning behaviors observed through individual computer device

\begin{tabular}{|c|c|c|c|c|c|c|c|c|c|c|c|c|c|c|}
\hline & ENGAGE & EXPLORE & REVIEW & SUMMARY & ASK & IB Total & GROUP & DISCUSS & CB Total & SURFACE & SURF & OFF & OTHER & MPB Total \\
\hline LK & $\begin{array}{c}1695 \\
(14.3 \%) \\
\end{array}$ & $\begin{array}{c}640 \\
(5.2 \%) \\
\end{array}$ & $\begin{array}{c}968 \\
(8.3 \%) \\
\end{array}$ & $\begin{array}{c}11 \\
(0.1 \%)\end{array}$ & $\begin{array}{c}361 \\
(3.5 \%) \\
\end{array}$ & $\begin{array}{c}3675 \\
(31.3 \%) \\
\end{array}$ & $\begin{array}{c}76 \\
(0.6 \%) \\
\end{array}$ & $\begin{array}{c}442 \\
(3.8 \%) \\
\end{array}$ & $\begin{array}{c}518 \\
(4.5 \%) \\
\end{array}$ & $\begin{array}{c}774 \\
(6.9 \%) \\
\end{array}$ & $\begin{array}{c}171 \\
(1.5 \%)\end{array}$ & $\begin{array}{c}5211 \\
(48.3 \%) \\
\end{array}$ & $\begin{array}{c}733 \\
(7.4 \%) \\
\end{array}$ & $\begin{array}{c}6889 \\
(64.2 \%) \\
\end{array}$ \\
\hline $\begin{array}{l}\text { GroupA } \\
\text { (Female) }\end{array}$ & $\begin{array}{c}1636 \\
(27.3 \%) \\
\end{array}$ & $\begin{array}{c}581 \\
(9.3 \%) \\
\end{array}$ & $\begin{array}{c}859 \\
(14.6 \%) \\
\end{array}$ & $\begin{array}{c}11 \\
(0.2 \%) \\
\end{array}$ & $\begin{array}{c}74 \\
(1.2 \%) \\
\end{array}$ & $\begin{array}{c}3161 \\
(52.6 \%) \\
\end{array}$ & $\begin{array}{c}65 \\
(1.1 \%) \\
\end{array}$ & $\begin{array}{c}430 \\
(7.4 \%) \\
\end{array}$ & $\begin{array}{c}495 \\
(8.5 \%) \\
\end{array}$ & $\begin{array}{c}475 \\
(7.9 \%) \\
\end{array}$ & $\begin{array}{c}78 \\
(1.3 \%) \\
\end{array}$ & $\begin{array}{c}1826 \\
(29.7 \%) \\
\end{array}$ & $\begin{array}{c}0 \\
(0 \%) \\
\end{array}$ & $\begin{array}{c}2379 \\
(38.9 \%) \\
\end{array}$ \\
\hline 7210 & $\begin{array}{c}664 \\
(21.2 \%)\end{array}$ & $\begin{array}{c}581 \\
(18.5 \%)\end{array}$ & $\begin{array}{c}183 \\
(5.8 \%)\end{array}$ & $\begin{array}{c}11 \\
(0.4 \%)\end{array}$ & $\begin{array}{c}45 \\
(1.4 \%)\end{array}$ & $\begin{array}{c}1484 \\
(47.4 \%)\end{array}$ & $\begin{array}{c}32 \\
(1 \%)\end{array}$ & $\begin{array}{c}0 \\
(0 \%)\end{array}$ & $\begin{array}{c}32 \\
(1 \%)\end{array}$ & $\begin{array}{c}225 \\
(7.2 \%)\end{array}$ & $\begin{array}{c}46 \\
(1.5 \%)\end{array}$ & $\begin{array}{c}1346 \\
(43.1 \%)\end{array}$ & $\begin{array}{c}0 \\
(0 \%)\end{array}$ & $\begin{array}{c}1617 \\
(51.6 \%)\end{array}$ \\
\hline 7602 & $\begin{array}{c}972 \\
(33.5 \%) \\
\end{array}$ & $\begin{array}{c}0 \\
(0 \%) \\
\end{array}$ & $\begin{array}{c}676 \\
(23.3 \%) \\
\end{array}$ & $\begin{array}{c}0 \\
(0 \%) \\
\end{array}$ & $\begin{array}{c}29 \\
(1 \%) \\
\end{array}$ & $\begin{array}{c}1677 \\
(57.8 \%) \\
\end{array}$ & $\begin{array}{c}33 \\
(1.1 \%) \\
\end{array}$ & $\begin{array}{c}430 \\
(14.8 \%) \\
\end{array}$ & $\begin{array}{c}463 \\
(16 \%) \\
\end{array}$ & $\begin{array}{c}250 \\
(8.6 \%) \\
\end{array}$ & $\begin{array}{c}32 \\
(1.1 \%) \\
\end{array}$ & $\begin{array}{c}480 \\
(16.5 \%) \\
\end{array}$ & $\begin{array}{c}0 \\
(0 \%) \\
\end{array}$ & $\begin{array}{c}762 \\
(26.3 \%) \\
\end{array}$ \\
\hline $\begin{array}{l}\text { GroupB } \\
\text { (Male) }\end{array}$ & $\begin{array}{c}59 \\
(1.2 \%) \\
\end{array}$ & $\begin{array}{c}59 \\
(1.1 \%) \\
\end{array}$ & $\begin{array}{c}109 \\
(2 \%) \\
\end{array}$ & $\begin{array}{c}0 \\
(0 \%) \\
\end{array}$ & $\begin{array}{c}287 \\
(5.8 \%) \\
\end{array}$ & $\begin{array}{c}514 \\
(10.1 \%) \\
\end{array}$ & $\begin{array}{c}11 \\
(0.2 \%) \\
\end{array}$ & $\begin{array}{c}12 \\
(0.2 \%) \\
\end{array}$ & $\begin{array}{c}23 \\
(0.4 \%) \\
\end{array}$ & $\begin{array}{c}299 \\
(5.9 \%) \\
\end{array}$ & $\begin{array}{c}93 \\
(1.7 \%) \\
\end{array}$ & $\begin{array}{c}3385 \\
(67 \%) \\
\end{array}$ & $\begin{array}{c}733 \\
(14.9 \%) \\
\end{array}$ & $\begin{array}{c}4510 \\
(89.5 \%) \\
\end{array}$ \\
\hline 5762 & $\begin{array}{c}39 \\
(1.7 \%)\end{array}$ & $\begin{array}{c}0 \\
(0 \%)\end{array}$ & $\begin{array}{c}8 \\
(0.3 \%)\end{array}$ & $\begin{array}{c}0 \\
(0 \%)\end{array}$ & $\begin{array}{c}168 \\
(7.2 \%)\end{array}$ & $\begin{array}{c}215 \\
(9.2 \%)\end{array}$ & $\begin{array}{c}0 \\
(0 \%)\end{array}$ & $\begin{array}{c}0 \\
(0 \%)\end{array}$ & $\begin{array}{c}0 \\
(0 \%)\end{array}$ & $\begin{array}{c}113 \\
(4.8 \%)\end{array}$ & $\begin{array}{c}0 \\
(0 \%)\end{array}$ & $\begin{array}{c}1544 \\
(65.9 \%)\end{array}$ & $\begin{array}{c}471 \\
(20.1 \%)\end{array}$ & $\begin{array}{c}2128 \\
(90.8 \%)\end{array}$ \\
\hline 7763 & $\begin{array}{c}20 \\
(0.7 \%) \\
\end{array}$ & $\begin{array}{c}59 \\
(2.2 \%) \\
\end{array}$ & $\begin{array}{c}101 \\
(3.7 \%) \\
\end{array}$ & $\begin{array}{c}0 \\
(0 \%) \\
\end{array}$ & $\begin{array}{c}119 \\
(4.4 \%) \\
\end{array}$ & $\begin{array}{c}299 \\
(11.1 \%) \\
\end{array}$ & $\begin{array}{c}11 \\
(0.4 \%) \\
\end{array}$ & $\begin{array}{c}12 \\
(0.4 \%) \\
\end{array}$ & $\begin{array}{c}23 \\
(0.9 \%) \\
\end{array}$ & $\begin{array}{c}186 \\
(6.9 \%) \\
\end{array}$ & $\begin{array}{c}93 \\
(3.4 \%) \\
\end{array}$ & $\begin{array}{c}1841 \\
(68.1 \%) \\
\end{array}$ & $\begin{array}{c}262 \\
(9.7 \%) \\
\end{array}$ & $\begin{array}{c}2382 \\
(88.1 \%) \\
\end{array}$ \\
\hline HK & $\begin{array}{c}3521 \\
(7.3 \%) \\
\end{array}$ & $\begin{array}{c}2782 \\
(7.4 \%) \\
\end{array}$ & $\begin{array}{c}5840 \\
(17.2 \%) \\
\end{array}$ & $\begin{array}{c}774 \\
(1.9 \%) \\
\end{array}$ & $\begin{array}{c}1521 \\
(3.6 \%) \\
\end{array}$ & $\begin{array}{c}14438 \\
(37.5 \%) \\
\end{array}$ & $\begin{array}{c}1371 \\
(3.3 \%) \\
\end{array}$ & $\begin{array}{c}8332 \\
(19.8 \%) \\
\end{array}$ & $\begin{array}{c}9703 \\
(23.1 \%) \\
\end{array}$ & $\begin{array}{c}4685 \\
(10.7 \%) \\
\end{array}$ & $\begin{array}{c}757 \\
(1.9 \%) \\
\end{array}$ & $\begin{array}{c}9019 \\
(22.9 \%) \\
\end{array}$ & $\begin{array}{c}1612 \\
(3.9 \%) \\
\end{array}$ & $\begin{array}{c}16073 \\
(39.4 \%) \\
\end{array}$ \\
\hline $\begin{array}{l}\text { GroupC } \\
\text { (Male) }\end{array}$ & $\begin{array}{c}425 \\
(3.8 \%) \\
\end{array}$ & $\begin{array}{c}453 \\
(3.8 \%) \\
\end{array}$ & $\begin{array}{c}247 \\
(2.2 \%) \\
\end{array}$ & $\begin{array}{c}404 \\
(3.6 \%) \\
\end{array}$ & $\begin{array}{c}195 \\
(1.8 \%) \\
\end{array}$ & $\begin{array}{c}1724 \\
(15.2 \%) \\
\end{array}$ & $\begin{array}{c}322 \\
(2.7 \%) \\
\end{array}$ & $\begin{array}{c}2164 \\
(19.1 \%) \\
\end{array}$ & $\begin{array}{c}2486 \\
(21.8 \%) \\
\end{array}$ & $\begin{array}{c}1265 \\
(11.4 \%) \\
\end{array}$ & $\begin{array}{c}425 \\
(3.7 \%) \\
\end{array}$ & $\begin{array}{c}4705 \\
(41.3 \%) \\
\end{array}$ & $\begin{array}{c}767 \\
(6.6 \%) \\
\end{array}$ & $\begin{array}{c}7162 \\
(63 \%) \\
\end{array}$ \\
\hline 2277 & $\begin{array}{c}179 \\
(4.4 \%)\end{array}$ & $\begin{array}{c}281 \\
(7 \%)\end{array}$ & $\begin{array}{c}130 \\
(3.2 \%)\end{array}$ & $\begin{array}{c}147 \\
(3.7 \%)\end{array}$ & $\begin{array}{c}24 \\
(0.6 \%)\end{array}$ & $\begin{array}{c}761 \\
(18.9 \%)\end{array}$ & $\begin{array}{c}266 \\
(6.6 \%)\end{array}$ & $\begin{array}{c}928 \\
(23 \%)\end{array}$ & $\begin{array}{c}1194 \\
(29.6 \%)\end{array}$ & $\begin{array}{c}254 \\
(6.3 \%)\end{array}$ & $\begin{array}{c}189 \\
(4.7 \%)\end{array}$ & $\begin{array}{c}1167 \\
(29 \%)\end{array}$ & $\begin{array}{c}462 \\
(11.5 \%)\end{array}$ & $\begin{array}{c}2072 \\
(51.5 \%)\end{array}$ \\
\hline 9153 & $\begin{array}{c}177 \\
(5.1 \%)\end{array}$ & $\begin{array}{c}38 \\
(1.1 \%)\end{array}$ & $\begin{array}{c}95 \\
(2.7 \%)\end{array}$ & $\begin{array}{c}165 \\
(4.8 \%)\end{array}$ & $\begin{array}{c}89 \\
(2.6 \%)\end{array}$ & $\begin{array}{c}564 \\
(16.3 \%)\end{array}$ & $\begin{array}{c}4 \\
(0.1 \%)\end{array}$ & $\begin{array}{c}775 \\
(22.4 \%)\end{array}$ & $\begin{array}{c}779 \\
(22.5 \%)\end{array}$ & $\begin{array}{c}584 \\
(16.9 \%)\end{array}$ & $\begin{array}{c}103 \\
(3 \%)\end{array}$ & $\begin{array}{c}1270 \\
(36.7 \%)\end{array}$ & $\begin{array}{c}157 \\
(4.5 \%)\end{array}$ & $\begin{array}{c}2114 \\
(61.2 \%)\end{array}$ \\
\hline 9428 & $\begin{array}{c}69 \\
(1.8 \%) \\
\end{array}$ & $\begin{array}{c}134 \\
(3.4 \%)\end{array}$ & $\begin{array}{c}22 \\
(0.6 \%) \\
\end{array}$ & $\begin{array}{c}92 \\
(2.4 \%) \\
\end{array}$ & $\begin{array}{c}82 \\
(2.1 \%) \\
\end{array}$ & $\begin{array}{c}399 \\
(10.3 \%) \\
\end{array}$ & $\begin{array}{c}52 \\
(1.3 \%) \\
\end{array}$ & $\begin{array}{c}461 \\
(11.9 \%) \\
\end{array}$ & $\begin{array}{c}513 \\
(13.2 \%) \\
\end{array}$ & $\begin{array}{c}427 \\
(11 \%) \\
\end{array}$ & $\begin{array}{c}133 \\
(3.4 \%) \\
\end{array}$ & $\begin{array}{c}2268 \\
(58.3 \%) \\
\end{array}$ & $\begin{array}{c}148 \\
(3.8 \%) \\
\end{array}$ & $\begin{array}{c}2976 \\
(76.5 \%) \\
\end{array}$ \\
\hline $\begin{array}{l}\text { GroupD } \\
\text { (Female) }\end{array}$ & $\begin{array}{c}677 \\
(4.5 \%) \\
\end{array}$ & $\begin{array}{c}1919 \\
(12.2 \%) \\
\end{array}$ & $\begin{array}{c}2111 \\
(13.8 \%) \\
\end{array}$ & $\begin{array}{c}182 \\
(1.2 \%) \\
\end{array}$ & $\begin{array}{c}731 \\
(5 \%) \\
\end{array}$ & $\begin{array}{c}5620 \\
(36.5 \%) \\
\end{array}$ & $\begin{array}{c}595 \\
(3.8 \%) \\
\end{array}$ & $\begin{array}{c}3251 \\
(21.2 \%) \\
\end{array}$ & $\begin{array}{c}3846 \\
(25 \%) \\
\end{array}$ & $\begin{array}{c}2383 \\
(13.7 \%) \\
\end{array}$ & $\begin{array}{c}214 \\
(1.4 \%) \\
\end{array}$ & $\begin{array}{c}3145 \\
(21 \%) \\
\end{array}$ & $\begin{array}{c}401 \\
(2.3 \%) \\
\end{array}$ & $\begin{array}{c}6143 \\
(38.4 \%) \\
\end{array}$ \\
\hline 2344 & $\begin{array}{c}159 \\
(4 \%)\end{array}$ & $\begin{array}{c}806 \\
(20.4 \%)\end{array}$ & $\begin{array}{c}437 \\
(11.1 \%)\end{array}$ & $\begin{array}{c}182 \\
(4.6 \%)\end{array}$ & $\begin{array}{c}180 \\
(4.6 \%)\end{array}$ & $\begin{array}{c}1764 \\
(44.7 \%)\end{array}$ & $\begin{array}{c}0 \\
(0 \%)\end{array}$ & $\begin{array}{c}1001 \\
(25.4 \%)\end{array}$ & $\begin{array}{c}1001 \\
(25.4 \%)\end{array}$ & $\begin{array}{c}155 \\
(3.9 \%)\end{array}$ & $\begin{array}{c}61 \\
(1.5 \%)\end{array}$ & $\begin{array}{c}967 \\
(24.5 \%)\end{array}$ & $\begin{array}{c}0 \\
(0 \%)\end{array}$ & $\begin{array}{c}1183 \\
(30 \%)\end{array}$ \\
\hline 3804 & $\begin{array}{c}300 \\
(8.5 \%)\end{array}$ & $\begin{array}{c}359 \\
(10.1 \%)\end{array}$ & $\begin{array}{c}641 \\
(18.1 \%)\end{array}$ & $\begin{array}{c}0 \\
(0 \%)\end{array}$ & $\begin{array}{c}361 \\
(10.2 \%)\end{array}$ & $\begin{array}{c}1661 \\
(46.9 \%)\end{array}$ & $\begin{array}{c}229 \\
(6.5 \%)\end{array}$ & $\begin{array}{c}926 \\
(26.2 \%)\end{array}$ & $\begin{array}{c}1155 \\
(32.6 \%)\end{array}$ & $\begin{array}{c}36 \\
(1 \%)\end{array}$ & $\begin{array}{c}52 \\
(1.5 \%)\end{array}$ & $\begin{array}{c}589 \\
(16.6 \%)\end{array}$ & $\begin{array}{c}45 \\
(1.3 \%)\end{array}$ & $\begin{array}{c}722 \\
(20.4 \%)\end{array}$ \\
\hline 8343 & $\begin{array}{c}107 \\
(2.9 \%)\end{array}$ & $\begin{array}{c}243 \\
(6.6 \%)\end{array}$ & $\begin{array}{c}579 \\
(15.7 \%)\end{array}$ & $\begin{array}{c}0 \\
(0 \%)\end{array}$ & $\begin{array}{c}180 \\
(4.9 \%)\end{array}$ & $\begin{array}{c}1109 \\
(30.1 \%)\end{array}$ & $\begin{array}{c}94 \\
(2.6 \%)\end{array}$ & $\begin{array}{c}770 \\
(20.9 \%)\end{array}$ & $\begin{array}{c}864 \\
(23.4 \%)\end{array}$ & $\begin{array}{c}95 \\
(2.6 \%)\end{array}$ & $\begin{array}{c}87 \\
(2.4 \%)\end{array}$ & $\begin{array}{c}1531 \\
(41.5 \%)\end{array}$ & $\begin{array}{c}0 \\
(0 \%)\end{array}$ & $\begin{array}{c}1713 \\
(46.5 \%)\end{array}$ \\
\hline 9446 & $\begin{array}{c}111 \\
(2.5 \%) \\
\end{array}$ & $\begin{array}{c}511 \\
(11.5 \%) \\
\end{array}$ & $\begin{array}{c}454 \\
(10.2 \%) \\
\end{array}$ & $\begin{array}{c}0 \\
(0 \%) \\
\end{array}$ & $\begin{array}{c}10 \\
(0.2 \%) \\
\end{array}$ & $\begin{array}{c}1086 \\
(24.5 \%) \\
\end{array}$ & $\begin{array}{c}272 \\
(6.1 \%) \\
\end{array}$ & $\begin{array}{c}554 \\
(12.5 \%) \\
\end{array}$ & $\begin{array}{c}826 \\
(18.6 \%) \\
\end{array}$ & $\begin{array}{c}2097 \\
(47.3 \%) \\
\end{array}$ & $\begin{array}{c}14 \\
(0.3 \%) \\
\end{array}$ & $\begin{array}{c}58 \\
(1.3 \%) \\
\end{array}$ & $\begin{array}{c}356 \\
(8 \%) \\
\end{array}$ & $\begin{array}{c}2525 \\
(56.9 \%) \\
\end{array}$ \\
\hline $\begin{array}{l}\text { GroupE } \\
\text { (Female) }\end{array}$ & $\begin{array}{c}2419 \\
(14.6 \%) \\
\end{array}$ & $\begin{array}{c}410 \\
(4.5 \%) \\
\end{array}$ & $\begin{array}{c}3482 \\
(36.9 \%) \\
\end{array}$ & $\begin{array}{c}188 \\
(1.3 \%) \\
\end{array}$ & $\begin{array}{c}595 \\
(3.7 \%) \\
\end{array}$ & $\begin{array}{c}7094 \\
(61.1 \%) \\
\end{array}$ & $\begin{array}{c}454 \\
(3.2 \%) \\
\end{array}$ & $\begin{array}{c}2917 \\
(18.7 \%) \\
\end{array}$ & $\begin{array}{c}3371 \\
(21.9 \%) \\
\end{array}$ & $\begin{array}{c}1037 \\
(5.9 \%) \\
\end{array}$ & $\begin{array}{c}118 \\
(0.8 \%) \\
\end{array}$ & $\begin{array}{c}1169 \\
(6.9 \%) \\
\end{array}$ & $\begin{array}{c}444 \\
(3.3 \%) \\
\end{array}$ & $\begin{array}{c}2768 \\
(17 \%) \\
\end{array}$ \\
\hline 1167 & $\begin{array}{c}1478 \\
(20.2 \%)\end{array}$ & $\begin{array}{c}48 \\
(0.7 \%)\end{array}$ & $\begin{array}{c}1001 \\
(13.6 \%)\end{array}$ & $\begin{array}{c}73 \\
(1 \%)\end{array}$ & $\begin{array}{c}326 \\
(4.4 \%)\end{array}$ & $\begin{array}{c}2926 \\
(39.9 \%)\end{array}$ & $\begin{array}{c}245 \\
(3.3 \%)\end{array}$ & $\begin{array}{c}1981 \\
(27 \%)\end{array}$ & $\begin{array}{c}2226 \\
(30.4 \%)\end{array}$ & $\begin{array}{c}790 \\
(10.8 \%)\end{array}$ & $\begin{array}{c}81 \\
(1.1 \%)\end{array}$ & $\begin{array}{c}1030 \\
(14 \%)\end{array}$ & $\begin{array}{c}281 \\
(3.8 \%)\end{array}$ & $\begin{array}{c}2182 \\
(29.8 \%)\end{array}$ \\
\hline 2869 & $\begin{array}{c}0 \\
(0 \%)\end{array}$ & $\begin{array}{c}140 \\
(7.2 \%)\end{array}$ & $\begin{array}{c}1307 \\
(67.5 \%)\end{array}$ & $\begin{array}{c}0 \\
(0 \%)\end{array}$ & $\begin{array}{c}0 \\
(0 \%)\end{array}$ & $\begin{array}{c}1447 \\
(74.7 \%)\end{array}$ & $\begin{array}{c}41 \\
(2.1 \%)\end{array}$ & $\begin{array}{c}202 \\
(10.4 \%)\end{array}$ & $\begin{array}{c}243 \\
(12.6 \%)\end{array}$ & $\begin{array}{c}32 \\
(1.7 \%)\end{array}$ & $\begin{array}{c}11 \\
(0.6 \%)\end{array}$ & $\begin{array}{c}124 \\
(6.4 \%)\end{array}$ & $\begin{array}{c}79 \\
(4.1 \%)\end{array}$ & $\begin{array}{c}246 \\
(12.7 \%)\end{array}$ \\
\hline 8835 & $\begin{array}{c}941 \\
(23.7 \%) \\
\end{array}$ & $\begin{array}{c}222 \\
(5.6 \%) \\
\end{array}$ & $\begin{array}{c}1174 \\
(29.6 \%) \\
\end{array}$ & $\begin{array}{c}115 \\
(2.9 \%) \\
\end{array}$ & $\begin{array}{c}269 \\
(6.8 \%) \\
\end{array}$ & $\begin{array}{c}2721 \\
(68.7 \%) \\
\end{array}$ & $\begin{array}{c}168 \\
(4.2 \%) \\
\end{array}$ & $\begin{array}{c}734 \\
(18.5 \%) \\
\end{array}$ & $\begin{array}{c}902 \\
(22.8 \%) \\
\end{array}$ & $\begin{array}{c}215 \\
(5.4 \%) \\
\end{array}$ & $\begin{array}{c}26 \\
(0.7 \%) \\
\end{array}$ & $\begin{array}{c}15 \\
(0.4 \%) \\
\end{array}$ & $\begin{array}{c}84 \\
(2.1 \%) \\
\end{array}$ & $\begin{array}{c}340 \\
(8.6 \%) \\
\end{array}$ \\
\hline $\begin{array}{l}\text { Grand } \\
\text { Total }\end{array}$ & $\begin{array}{c}5216 \\
(9.3 \%) \\
\end{array}$ & $\begin{array}{c}3422 \\
(6.7 \%)\end{array}$ & $\begin{array}{c}6808 \\
(14.7 \%) \\
\end{array}$ & $\begin{array}{c}785 \\
(1.4 \%) \\
\end{array}$ & $\begin{array}{c}1882 \\
(3.6 \%) \\
\end{array}$ & $\begin{array}{c}18113 \\
(35.7 \%) \\
\end{array}$ & $\begin{array}{c}1447 \\
(2.5 \%)\end{array}$ & $\begin{array}{c}8774 \\
(15.2 \%) \\
\end{array}$ & $\begin{array}{c}10221 \\
(17.8 \%) \\
\end{array}$ & $\begin{array}{c}5459 \\
(9.6 \%) \\
\end{array}$ & $\begin{array}{c}928 \\
(1.8 \%)\end{array}$ & $\begin{array}{c}14230 \\
(30.2 \%) \\
\end{array}$ & $\begin{array}{c}2345 \\
(4.9 \%)\end{array}$ & $\begin{array}{c}22962 \\
(46.5 \%) \\
\end{array}$ \\
\hline
\end{tabular}


Note: Seconds (proportion of each row), LK = Low prior knowledge group, HK = High prior knowledge group, IB $=$ Inquiry Behavior, $\mathrm{CB}=$ Collaborative Behaviors, $\mathrm{MPB}=$ Minimally Productive Behavior. 
Table 5. Intercorrelations between learning behaviors and academic performance

$\begin{array}{lllll}1 & 2 & 3 & 4 & 5\end{array}$

Proportional time on the types of learning behaviors

1. Pre-test

2. Inquiry behaviors

3. Collaborative behaviors

4. Minimally productive behaviors

5. Post-test

$\begin{array}{llll}.16 & .77 * * & -.45 & .23 \\ - & .22 & -.91 * * & .77 * * \\ - & -.60 * & .39 \\ & & -.80 * * \\ & & & \end{array}$

Actual time on the types of learning behaviors

$$
.30
$$$$
.59^{*}
$$

$-.21$

.23

2. Inquiry behaviors

3. Collaborative behaviors

4. Minimally productive behaviors

5. Post-test

$.62 * \quad-.57 * \quad .72 * *$

$\begin{array}{lll}- & -.02 & .33\end{array}$

$-\quad-.74 * *$ 
Activity: 3-Genetic Predetermination to Environmental Influence Continuum 2

Describe the difference between genetic predispositions, environmental causes, and genetically predetermined traits.

1.) Watch the following video clip about the use of personal genetic information

Video Clip about Miss District of Columbia

2.) Read Article about Miss District of Columbia and answer questions about it.

Miss District of Columbia Personal

Decision Article and Questions

3.) Use your prior knowledge to complete the following exercise.

Google Form for Placement on Continuum from Genetically Predetermined to

Environmental

4.) Classroom Discussion over the results of the form completion.

13 Comments Shares / Tweets / Stumble / Email

More +

A Miss America contestant has announced she will undergo a preventive double mastectomy to avoid the disease that took her mother's life prematurely.

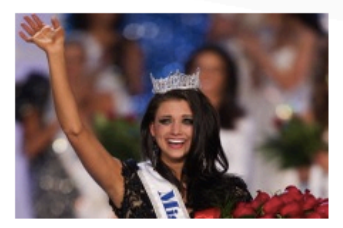

34 PHOTоS

Miss America 2012

hav thought that other breast removed, but I'm sure there was a part of her that begged her for years and years to get it removed, but she said no. It's ultimately the thing that killed her," she told the magazine.

Rose told ABC's Good Morning America on Monday, that she read her late

Figure 1. The developed 'Genetic Information' unit as it appears on students' mobile devices. 